\title{
KUALITAS SUBYEKTIF SIPUS V3 DAN INFORMASI KELUARANNYA SEBAGAI PENDUKUNG KEPUTUSAN
}

\author{
Disusun Oleh :
}

Maryono' dan Tri Septiyantono ${ }^{2}$

\begin{abstract}
This research entitled "The Subjective Quality of Sipus V3 software and its Information Output as a Support for Decision Making" was motivated by several problems happening during two years in the application of the software. Such automation software is expected to be able to support the success of library services and to produce statistical information for a decision making. The research aims to find out the quality of Sipus V3 software and its statistical information output, and the use of the output for supporting decision making. The research describes the subjective quality of Sipus V3 software, its statistical information output, and the use of the output in decision making process. The research employs a questionnaire method to collect data and its respondents are 44 librarians involving in Sipus V3 and 26 persons working at the information management department responsible for the statistic output of Sipus V3. By using a mean method for each indicator value, the result of the research shows that the high indicator score of Sipus V3 software quality as follows: usability-operability 3,75; efficiency of resources 3,75; efficiency of time behavior 3,68; usability-understandability 3,64; functionality-suitability 3,55; maintainability-stability for the rules of lending period and the number of items borrowed 3,43; reliabilityrecoverability 3,30; and maintainability-stability for holiday/closing days 3,20. In contrast, the low indicator score can be seen in the following: functionality-accuracy 2,84; and reliability-maturity 2,68. Furthermore the indicator score of Sipus V3 statistical information which is high is timeliness 3,31; conciseness 3,23; relevancy 3,15; and completeness 3,15. Whereas the low indicator score is accuracy 2,92. The use of Sipus V3 statistical information is very low, i.e. planning policy of circulation services 2,96; planning policy of collection development 2,88; library planning 2,69; and staffing for circulation staff 2,65.
\end{abstract}

Keywords : library automation, software quality, information quality, decision support system

1. Pustakawan UGM

2. Pustakawan UGM, Dosen UIN Sunan Kalijaga Yogyakarta

\section{PENDAHULUAN}

Otomasi perpustakaan, merupakan alat bantu untuk mempertahankan dan meningkatkan kinerja layanan perpustakaan. Dengan penerapan otomasi perpustakaan, berbagai tugas dan pekerjaan yang tadinya dikerjakan dengan tangan atau secara manual (manually), sekarang bisa dikerjakan dengan mesin. Alat bantu mesin tersebut, terdiri dari teknologi informasi dan komunikasi.

Dalam organisasi perpustakaan, peran teknologi informasi dan komunikasi sangat nyata dalam berbagai fungsi pekerjaan. Fungsi-fungsi pekerjaan di perpustakaan akan sangat sukar dipertahankan ataupun ditingkatkan kinerjanya, tanpa sarana bantu perangkat lunak otomasi. Sipus V3 merupakan perangkat lunak sistem otomasi layanan sirkulasi Perpustakaan UGM. Dalam mendukung kegiatan operasional, sering ditemukan permasalahan. Tanggal pengembalian buku paling sering dikeluhkan sebagai tidak tepat. Permasalahan itulah yang akan diungkap melalui penelitian survei terhadap staf operator Sipus. Untuk itu digunakan pengukuran kualitas perangkat lunak dengan menggunakan indikator berupa faktor kualitas perangkat lunak. Terdapat beberapa model kualitas perangkat lunak, antara lain standar ISO 9126 (Berander dkk, 2005:12).

Kualitas informasi yang dihasilkan dari kegiatan statistik perpustakaan, dan berguna sebagai pendukung pengambilan keputusan untuk berbagai pihak terkait, sering dirasakan kurang memadai. Hawks (1998:131), menyebutkan "the essence of good management is good information". Inti persoalan manajemen yang sukses adalah informasi yang berkualitas. 
Dalam hal sistem otomasi perpustakaan, informasi statistik banyak dihasilkan dari layanan sirkulasi. Informasi tanggal pengembalian buku dan denda yang dihasilkan oleh statistik Sipus V3, paling sering dikeluhkan tidak akurat, dan tidak konsisten. Berdasarkan uraian tersebut di atas, maka diperlukan pengukuran kualitas informasi statistik yang dihasilkan, menggunakan indikator akurasi, ketepatan waktu, relevansi, kelengkapan dan keringkasan. Indikator kualitas informasi tersebut berasal dari faktor kualitas informasi menurut Amsyah (2001:316).

\section{Tujuan Penelitian}

Penelitian ini bertujuan untuk mengetahui kualitas perangkat lunak Sipus V3 di UGM, kualitas informasi statistik keluaran Sipus V3 di UGM, serta mengungkap status penggunaan informasi statistik keluaran Sipus V3 di UGM.

\section{Landasan Teori}

Hawks (1988:131), menyatakan bahwa sebagian besar sistem otomasi perpustakaan dirancang agar berfungsi ganda, yaitu mendukung kegiatan operasional perpustakaan dan menyediakan informasi berharga untuk membuat keputusan oleh manajemen. Sistem otomasi harus dievaluasi berdasarkan kemampuan menjalankan fungsi ganda tersebut.

\section{Kualitas Perangkat Lunak Otomasi Perpustakaan}

Menurut Gittens (2005:6), kebutuhan untuk penjaminan kualitas perangkat lunak meningkat dalam beberapa tahun terakhir. Kebutuhan tersebut sejalan dengan bertambahnya ukuran (size) dan derajat kompleksitas (degree of complexity) perangkat lunak.

Di samping itu, menurut Krasner (1998) dalam Lanman (2001:3), perangkat lunak kini berperan luas (pervasive), berperan penting, sangat menentukan dan merupakan teknologi yang riskan terhadap kegagalan (error prone technology).

Terdapat beberapa definisi kualitas, di antaranya menurut Edwards Deming, Armand
Vallin Feigenbaum, Kaoru Ishikawa, Joseph M. Juran, dan Walter A. Shewhart. Armand Vallin Feigenbaum dalam Berander dkk (2005:5), menjelaskan definisi kualitas, bahwa kualitas ditentukan oleh pelanggan, tidak ditentukan oleh pembuatnya, tidak oleh penjualnya, juga tidak oleh manajemen. Kualitas didasarkan atas pengalaman nyata pelanggan dengan suatu produk atau jasa, diukur menurut kebutuhannya, dinyatakan eksplisit atau implisit, disadari atau hanya dirasakan, keseluruhannya subyektif.

Berander dkk (2005:5) selanjutnya menyebutkan terdapat beberapa model kualitas secara terstruktur dan kuantitatif, di antaranya menurut Jim McCall, Barry W. Boehm, R. Geoff Dromey, ISO 9000, ISO 9126, ISO/IEC 15504 (SPICE), IEEE, dan CMM (Capability Maturity Model). Penelitian ini menggunakan beberapa faktor model kualitas ISO 9126, karena model tersebut memiliki seperangkat kriteria yang relevan dengan permasalahan perangkat lunak Sipus V3 UGM. 
Model kualitas tersebut dapat digambarkan secara ringkas sebagai berikut:

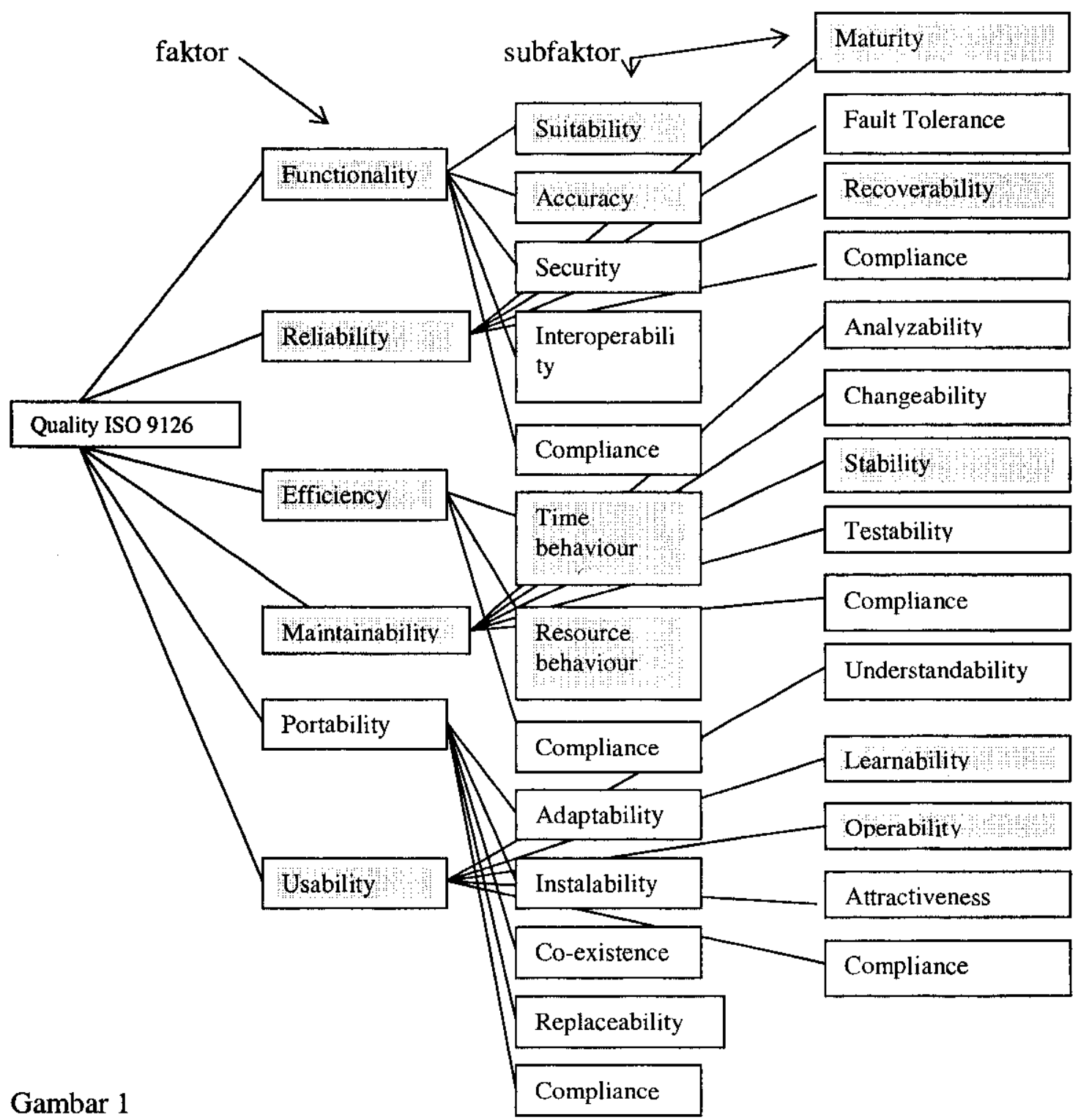

Model Kualitas ISO 9126

Sumber: Berander dkk (2005:13)

\section{Kualitas Informasi}

Amsyah (2001:316), menggunakan istilah "nilai informasi" dengan pengertian yang hampir sama dengan "kualitas informasi". Menurutnya nilai informasi ditentukan oleh lima karakteristik, yaitu: ketelitian (accuracy), ketepatan waktu (timeliness), kelengkapan (completeness), keringkasan (conciseness), dan kesesuaian (relevancy).

Penggunaan Informasi Statistik Keluaran Sistem Otomasi Perpustakaan Sebagai Pendukung Pengambilan Keputusan

Menurut Hiller dan James (2004:129), tingkat keterpakaian dan kualitas informasi untuk mendukung pengambilan keputusan dalam manajemen perpustakaan dan yang dihasilkan 
dari kegiatan operasional perpustakaan sangat bervariasi $\mathrm{di}$ antara berbagai perpustakaan. Banyak perpustakaan menyadari pentingnya penggunaan data untuk perencanaan dan pengambilan keputusan, tetapi mereka kebingungan, bagaimana sebaiknya mengumpulkan, menganalisis, . dan menggunakannya secara efektif dalam manajemen perpustakaan. Bidang kajian ini telah lama diusahakan oleh pustakawan. Bagaimanakah menggunakan statistik untuk meningkatkan efektivitas perpustakaan? Apa sebabnya banyak perpustakaan gagal menggunakan data statistik secara efektif? Apakah pustakawan telah mengumpulkan data statistik yang cocok sesuai kebutuhan?. Apakah data statistik tersebut benar dan dapat diperbandingkan dengan perpustakaan sejenis?. Pada awalnya kegiatan pengumpulan data digunakan untuk perencanaan, menurut Molyneux (1986) dalam Hiller dan James (2004), yaitu pertumbuhan koleksi perpustakaan. Perbandingan statistik juga digunakan untuk mengembangkan standar, misalnya jumlah minimal koleksi, staf dan jumlah tempat duduk.

Hawks (1988:136), menyatakan bahwa layanan sirkulasi merupakan sumber manajemen informasi yang besar. Perangkat lunak yang dirancang untuk layanan sirkulasi harus mampu menyediakan laporan tercetak berkaitan dengan peminjaman, pengembalian, pemesanan dan identifikasi keterlambatan pinjaman termasuk keuangannya. Hawks (1988:132), menjelaskan bahwa perangkat lunak otomasi juga mampu menghasilkan laporan statistik dalam bentuk rasio dan persentase, misalnya persentase peminjam dalam setiap bulannya. Selanjutnya Hawks (1988:136) menerangkan perangkat lunak otomasi memungkinkan pustakawan menganalisis busy times, dan mengantisipasinya dengan alokasi staf. Memungkinkan mengamati aktivitas peminjam, apakah dinon-aktifkan, apakah memiliki pinjaman terlambat dan sebagainya. Memungkinkan mengamati catatan pemesanan, jumlah pemesanan ataupun jumlah pesanan yang tidak diambil, juga adanya permasalahan pesanan yang tidak terpenuhi.

\section{Metode Penelitian}

Penelitian berjenis deskriptif ini menggunakan variabel-variabel kualitas perangkat lunak, kualitas informasi dan status penggunaan informasi statistik. Variabel kualitas perangkat lunak menggunakan standar ISO 9126 dan indikator yang digunakan tersusun dalam tabel berikut:

Tabel 1

Variabel Kualitas Perangkat Lunak dan Indikator

Variabel kualitas informasi menggunakan

faktor kualitas informasi Amsyah (2001:316)

\begin{tabular}{|c|c|c|c|}
\hline Variabel & Sub variabel & $\begin{array}{l}\text { Sub sub } \\
\text { variabel/indikator }\end{array}$ & Kcterangan \\
\hline \multirow{9}{*}{$\begin{array}{l}\text { Kualitas } \\
\text { Perangkat } \\
\text { lunak }\end{array}$} & \multirow[t]{2}{*}{ 1. Usability } & 1) Understandab & \multirow{9}{*}{$\begin{array}{l}\text { Dari enam faktor } \\
\text { kualitas software, lima } \\
\text { faktor digunakan } \\
\text { sebagai sub variabel. } \\
\text { Dari sembilan sub sub } \\
\text { variabel, dijabarkan } \\
\text { dalam sepuluh butir } \\
\text { pernyataan angket }\end{array}$} \\
\hline & & 2) Operability & \\
\hline & \multirow[t]{2}{*}{ 2. Functionality } & 1) Accuracy & \\
\hline & & 2) Suitability & \\
\hline & \multirow[t]{2}{*}{ 3. Reliability } & 1) Maturity & \\
\hline & & 2) Coverability & \\
\hline & 4. Maintainabili & 1) Stability & \\
\hline & \multirow[t]{2}{*}{ 5. Efficiency } & 1) Resources & \\
\hline & & 2) Time behavior & \\
\hline
\end{tabular}

sebagai indikator, dan tersusun dalam tabel berikut:

Tabel 2

Variabel Kualitas Informasi dan Indikator

\begin{tabular}{|l|l|l|}
\hline Variabel & Sub variabel/indikator & Keterangan \\
\hline Kualitas & 1. Akurasi & Lima indikator, \\
Informasi & $\begin{array}{l}\text { dijabarkan dalam } \\
\text { Statistik }\end{array}$ & $\begin{array}{l}\text { lima butir } \\
\text { pernyataan angket }\end{array}$ \\
\cline { 2 - 2 } & 3. Relevan waktu & \\
\cline { 2 - 3 } & 4. Kelengkapan & \\
\cline { 2 - 3 } & 5. Keringkasan & \\
\hline
\end{tabular}

Variabel status penggunaan informasi menggunakan beberapa penerapan yang utama, dan indikator yang digunakan tersusun dalam tabel berikut:

\section{Tabel 3}

Variabel Status Penggunaan Informasi dan Indikator

Teknik pengumpulan data yang digunakan adalah angket (questionnaire), observasi, dan dokumenter. Untuk bisa menghasilkan gradasi nilai, angket penelitian ini

\begin{tabular}{|c|c|c|}
\hline Variabel & Sub variabel/indikator & Keterangan \\
\hline \multirow{5}{*}{$\begin{array}{l}\text { Status } \\
\text { Penggunaan } \\
\text { Informasi Statistik }\end{array}$} & 1. Kebijakan layanan sirkulasi & \multirow{5}{*}{$\begin{array}{l}\text { Lima } \\
\text { indikator, } \\
\text { dijabarkan } \\
\text { dalam lima } \\
\text { butir } \\
\text { pemyataan }\end{array}$} \\
\hline & 2. Kebijakan pengembangan koleksi & \\
\hline & 3. Kebijakan dan pengaturan staf & \\
\hline & 4. Pengelolaan keuangan & \\
\hline & 5. Perencanaan perpustakaan & \\
\hline
\end{tabular}


menggunakan skala Likert. Sedangkan untuk menganalisis data digunakan metode rerata dan untuk menginterpretasikannya digunakan kategorisasi. Nilai rerata $<3$, dikategorikan sebagai nilai rendah. Untuk nilai rerata $\geq 3$, dikategorikan sebagai nilai tinggi. Kategorisasi seperti ini juga disarankan oleh Arikunto (2006:253).

\section{PEMBAHASAN \\ Gambaran Responden}

Dalam penelitian ini, responden angket kualitas perangkat lunak yang penulis gunakan adalah operator modul sirkulasi Sipus V3 yaitu semua staf sirkulasi, staf unit lain yang ikut piket sore, serta staf yang pernah bertugas di sirkulasi dan menggunakan modul sirkulasi sipus V3. Responden tersebut terdiri staf perpustakaan UGM dan staf perpustakaan fakultas (FE, FMIPA, FI) yang telah menggunakan Sipus V3.

\section{Tabel 4}

Responden Angket Kualitas Perangkat Lunak Sipus V3

\begin{tabular}{|l|l|l|}
\hline No. & Unit tugas & Jumlah \\
\hline 1. & Sirkulasi & 18 \\
\hline 2. & Unit lain dan ikut piket sore & 25 \\
\hline 3. & Unit lain dan pernah bertugas di sirkulasi & 7 \\
\hline Total & 50 \\
\hline \multicolumn{2}{|l|}{ Angket yang masuk dan sah } & 44 \\
\hline
\end{tabular}

Dari total 50 responden, hanya 44 angket yang masuk dan sah. Sisanya sebanyak 6 buah, dinyatakan tidak sah, tidak sempurna pengisiannya karena keterbatasan pengetahuan responden, dan tidak disertakan dalam pembahasan ini.

Sedangkan responden angket kualitas informasi statistik Sipus V3 dan status penggunaannya adalah para Penanggung Jawab dan mantan Penanggung Jawab yang merupakan manajemen, serta petugas statistik. Mereka adalah staf Perpustakaan UGM dan perpustakaan fakultas yang telah menggunakan Sipus V3 (FE, FMIPA, FI), dengan angket ini mereka menilai kualitas informasi dan penggunaannya untuk mendukung pengambilan keputusan.
Tabel 5

Responden Angket Kualitas Informasi Statistik Sipus V3

\begin{tabular}{|l|l|l|}
\hline No. & Unit tugas & Jumlah \\
\hline 1. & Penanggung Jawab & 16 \\
\hline 2. & Mantan Penanggung Jawab & 2 \\
\hline 3. & Petugas statistik & 8 \\
\hline Total & 30 \\
\hline \multicolumn{2}{|l|}{ Angket yang masuk dan sah } & 26 \\
\hline
\end{tabular}

Dari total 30 responden, hanya 26 angket yang masuk dan sah. Sisanya sebanyak 4 buah, dinyatakan tidak sah, tidak sempurna pengisiannya karena keterbatasan pengetahuan responden, dan tidak disertakan dalam pembahasan ini.

\section{Pengujian Validitas dan Reliabilitas}

Berdasarkan hasil perhitungan dengan menggunakan SPSS, maka ditentukan bahwa angket kualitas perangkat lunak yang memiliki 10 item dinyatakan valid dan reliabel. Demikian juga angket kualitas informasi dan status penggunaannya yang memiliki 9 item dinyatakan valid dan reliabel.

\section{Diskusi}

Data survei menunjukkan terdapat kelebihan dan kekurangan kualitas perangkat lunak, kualitas informasi dan penggunaannya yang cukup signifikan. Berdasarkan hasil analisis dengan menggunakan metode rerata, diperoleh data sebagai berikut :

\section{Kualitas Perangkat Lunak Sipus V3}

Peringkat indikator berdasarkan skor nilai rerata dapat dilihat sebagai berikut :

\section{Tabel 6}

Peringkat Skor Rerata Nilai Indikator Kualitas Perangkat Lunak Sipus V3

\begin{tabular}{|l|l|l|l|}
\hline No. & Indikator & Rerata & Kategori \\
\hline 1. & Usability-Operability & 3,75 & TINGGI \\
\hline 2. & Efficiency-Resources Staf & 3,75 & TINGGI \\
\hline 3. & Efficiency-Time Behavior & 3,68 & TINGGI \\
\hline 4. & Usability-Understandability & 3,64 & TINGGI \\
\hline 5. & Functionality-Suitability & 3,55 & TINGGI \\
\hline 6. & Maintainability-Stability & 3,43 & TINGGI \\
\hline 7. & Reliability-Recoverability & 3,30 & TINGGI \\
\hline 8. & Maintainability-Stability Hari & 3,20 & TINGGI \\
\hline 9. & Functionality-Accuracy & 2,84 & RENDAH \\
\hline 10. & Reliability-Maturity & 2,68 & RENDAH \\
\hline RERATA SEMUA BUTIR & $\mathbf{3 , 3 8}$ & \\
\hline
\end{tabular}


Dari tabel 6 di atas, terlihat bahwa indikator usability-operability memperoleh skor nilai tertinggi sebesar 3,75. Sipus V3 sangat mudah dijalankan, bahkan oleh staf kebersihan sekalipun, karena dikembangkan dengan pedoman untuk memberikan kemudahan bagi semua unsur yang berperan (easy for all). Sedangkan reliability-maturity memperoleh nilai terendah sebesar 2,68. Sipus V3 sering mengalami kemacetan, sewaktu dijalankan. Functionality-Accuracy memperoleh skor 2,84 secara meyakinkan sebagai bukti adanya permasalahan akurasi tanggal pengembalian, yang menjadi latar belakang permasalahan penelitian ini. Dua indikator memperoleh skor rendah, memerlukan penanganan lebih cermat.

\section{Kualitas Informasi Statistik Sipus V3}

Peringkat indikator berdasarkan skor nilai rerata dapat dilihat gambaran sebagai berikut :

\section{Tabel 7}

Peringkat Skor Rerata Nilai Indikator Kualitas Informasi Statistik Sipus V3

\begin{tabular}{|l|l|l|l|}
\hline No. & Indikator & Rerata nilai & Kategori \\
\hline 1. & Ketepatan Waktu & 3,31 & TINGGI \\
\hline 2. & Keringkasan & 3,23 & TINGGI \\
\hline 3. & Relevansi & 3,15 & TINGGI \\
\hline 4. & Kelengkapan & 3,15 & TINGGI \\
\hline 5. & Akurasi & 2,92 & RENDAH \\
\hline \multicolumn{2}{|l}{ RERATA SEMUA BUTIR } & $\mathbf{3 , 1 5}$ \\
\hline
\end{tabular}

Dari tabel 7 di atas, terlihat bahwa skor nilai tertinggi diperoleh indikator ketepatan waktu sebesar 3,31. Informasi statistik bisa diperoleh setiap saat. Sedangkan skor terendah diperoleh indikator akurasi sebesar 2,92. Informasi statistik yang dihasilkan Sipus V3 belum seluruhnya benar, ada sebagian statistik belum dapat dipercaya kebenarannya.

Akurasi informasi memperoleh skor rendah 2,92, antara lain disebabkan pada waktu transaksi peminjaman dan pengembalian terjadi ketidak tepatan tanggal pengembalian, mungkin juga karena jumlah denda yang menjadi tidak tepat disebabkan ketidaktepatan tanggal pengembalian.

\section{Status Penggunaan Informasi Statistik Sipus V3}

Peringkat indikator berdasarkan skor nilai rerata dapat dilihat gambaran sebagai berikut :

\section{Tabel 8}

Peringkat Skor Rerata Nilai Indikator Status Penggunaan Informasi Statistik Sipus V3

\begin{tabular}{|l|l|l|l|}
\hline No. & Indikator & Rerata & Kategori \\
\hline 1. & $\begin{array}{l}\text { Penggunaan informasi } \\
\text { statistik Sipus V3-kebijakan }\end{array}$ & 2,96 & RENDAH \\
\hline 2. & $\begin{array}{l}\text { Penggunaan informasi } \\
\text { statistik Sipus V3-kebijakan }\end{array}$ & 2,88 & RENDAH \\
\hline 3. & $\begin{array}{l}\text { Penggunaan informasi } \\
\text { statistik Sipus V3- }\end{array}$ & RENDAH \\
\hline 4. & $\begin{array}{l}\text { Penggunaan informasi } \\
\text { statistik Sipus V3- }\end{array}$ & 2,65 & RENDAH \\
\hline
\end{tabular}

Untuk status penggunaan, semua indikator memperoleh skor rendah. Responden kualitas informasi dan penggunaannya adalah pada tingkatan PJ atau manajemen operasional. Dengan skor hasil survei $<3$ di bawah cukup, mereka mengakui bahwa penggunaan informasi statistik belum optimal sebagaimana mestinya. Kemungkinan karena akurasinya rendah, juga kemungkinan karena rendahnya kesadaran pentingnya informasi statistik, juga kemungkinan proses pengambilan keputusan tidak didasarkan pada informasi statistik yang relevan, tetapi lebih didasarkan pada pertimbangan lain. Mungkin juga disebabkan ketidaktahuan bagaimana sebaiknya menggunakan informasi statistik secara efektif untuk pengambilan keputusan.

\section{PENUTUP}

Berdasarkan hasil analisis data, untuk variabel kualitas perangkat lunak Sipus V3, rerata semua butir sebesar 3,38 menunjukkan bahwa Sipus V3 berkualitas tinggi, meskipun terdapat kekurangan dalam hal akurasi (Functionality-Accuracy) dan adanya kemacetan (Reliability-Maturity). Rerata semua butir variabel kualitas informasi sebesar 3,15 menunjukkan bahwa informasi statistik Sipus V3 berkualitas tinggi dan juga masih terdapat kekurangan dalam hal akurasinya. Rerata semua butir variabel status penggunaan informasi sebesar 2,80; menunjukkan rendahnya keterpakaian statistik Sipus V3 untuk 
pengambilan keputusan yaitu penyusunan kebijakan layanan sirkulasi, penyusunan kebijakan pengembangan koleksi, pengaturan staf sirkulasi dan perencanaan perpustakaan.

\section{Saran}

Sipus V3 cukup sesuai digunakan di Perpustakaan UGM, terbukti dari nilai suitability yang tinggi. Karena itu kebijakan melanjutkan perbaikan secara cermat terhadap faktor-faktor kualitas Sipus V3 yang dikategorikan rendah perlu dilakukan, khususnya maturity, dan accuracy. Faktor maturity, perlu dikaji apakah terdapat kekeliruan skrip program (bugs), ataukah basis data dan bagian lainnya. Khusus accuracy tanggal pengembalian, perlu diperbaiki ekstra, karena dampaknya merugikan pengguna yang harus membayar denda lebih dari semestinya. Accuracy tanggal pengembalian yang rendah, kemungkinan juga berdampak pada accuracy informasi statistik denda yang dihasilkan. Perbaikan accuracy ini, mungkin sekaligus akan meningkatkan penggunaan dan keterpakaian informasi statistik Sipus V3.

Pengembangan sistem otomasi memerlukan dukungan sumber daya manusia, sebagai unsur utama (brainware). SDM berkualifikasi TI semakin diperlukan, mengingat makin tingginya prosentase tugas layanan perpustakaan yang menggunakan bantuan sistem otomasi, serta kondisi sains dan teknologi yang peka terhadap perubahan sangat cepat, dan efek globalisasi. Dalam hal ini, pengembangan SDM berkualifikasi TI sebagai prioritas merupakan langkah tepat dan strategis.

Pengukuran dan kajian kualitas perangkat lunak otomasi dan informasi keluarannya serta penggunaannya perlu dilanjutkan. Kegiatan tersebut bisa dilaksanakan lebih rinci mencakup berbagai faktor dan sub faktor kualitas. Dalam hal ini menggunakan berbagai pendekatan dan standar, sehingga dicapai keluasan dan kedalaman terhadap permasalahan otomasi. Demikian juga penelitian terhadap informasi keluaran perangkat lunak otomasi terpadu di berbagai unit layanan perpustakaan dan penggunaannya di berbagai tingkatan manajemen. Tiga pertanyaan yang dirumuskan dalam penelitian ini telah terjawab, dan memunculkan inspirasi untuk pertanyaan baru, yang juga membutuhkan jawaban. Pertanyaanpertanyaan itu adalah: Bagaimanakah pengaruh kualitas informasi statistik terhadap penggunaannya untuk mendukung pengambilan keputusan? bagaimanakah penerimaan dan penolakan perpustakaan fakultas terhadap Sipus V3, dan faktor-faktor apa saja yang mendasari keduanya? Bagaimanakah suatu sistem otomasi mampu menghasilkan informasi berkualitas? Bagaimanakah menggunakannya secara efektif untuk mendukung riset perpustakaan? dan Bagaimanakah menggunakannya secara efektif dalam pengambilan keputusan manajemen perpustakaan?

\section{DAFTAR PUSTAKA}

Amsyah, Zulkifli. 2001. Manajemen Sistem Informasi. Jakarta:Gramedia Pustaka Utama

Arikunto, Suharsimi. 2006. Prosedur penelitian suatu pendekatan praktek. Jakarta:Rineka Cipta

Berander, Patrik.dkk. 2005. Software quality attributes and trade-offs. [s.1]:Blekinge Institute of Technology. www.bth.se/tek/besq.nsf/(WebFiles)/5A52350 A52726F51C12570A8004CB613/\$FILE/Softw are_quality_attributes.pdf, akses 19 desember $2006 \mathrm{pk} 11.33 \mathrm{am}$

Gittens, Mechelle. 2005. SE641b Advanced Topics inSoftware Quality Assurance.[s.l.]:University of Western Ontario. www.csd.uwo.ca/courses/CS614b/Lecture1.pdf , akses 26 Februari 2007 pk 7:21 am

Hawks, Carol Pitts.1988. Management Information Gleaned from Automated Library Systems. Information Technology and Libraries; Jun 1988; 7, 2; Academic Research Library pg. 131.

Hiller, Steve dan James Self. 2004. From Measurement to Management : Using data wisely for planning and decision making.Library Trends, Urbana: Summer 2004.53(1); Academic Research Library.pg. 129.

Lanman, Jeremy T. 2001. Software measurements and management. [s.l.]: Embry-Riddle Aeronautical University 